Article

\title{
Seasonal Effect on Spatial and Temporal Consistency of the New GPM-Based IMERG-v5 and GSMaP-v7 Satellite Precipitation Estimates in Brazil's Central Plateau Region
}

\author{
Leandro Salles ${ }^{1,2, *} \mathbb{C}$, Frédéric Satgé ${ }^{3}$, Henrique Roig ${ }^{1}$, Tati Almeida ${ }^{1}$, Diogo Olivetti ${ }^{1}$ and \\ Welber Ferreira ${ }^{1,4}$ \\ 1 Instituto de Geociências (IG/UnB), Universidade de Brasília, CEP: 70910-900, Brasília-DF, Brazil; \\ roig@unb.br (H.R.); tati_almeida@unb.br (T.A.); di_olivetti@hotmail.com (D.O.); welber.fa@gmail.com (W.F.) \\ 2 Instituto Brasília Ambiental de Recursos Hídricos do Distrito Federal (IBRAM/DF), SEPN 511-Bloco \\ C-Edifício Bittar-CEP: 70.750-543 Brasília-DF, Brazil \\ 3 IRD, UMR 228 Espace-Dev, Maison de la télédétection, 500 rue JF Breton, 34093 Montpellier CEDEX 5, France; \\ frederic.satge@ird.fr \\ 4 Agência Reguladora de Águas, Energia e Saneamento do Distrito Federal (ADASA/DF), Saa Estação \\ Rodo-Ferroviária de Brasília - Ala Norte, CEP: 70.631-900 Brasília-DF, Brazil \\ * Correspondence: leandro.almeida.salles@gmail.com; Tel.: +55-61-3214-5647
}

Received: 28 February 2019; Accepted: 20 March 2019; Published: 31 March 2019

\begin{abstract}
This study assesses the performance of the new Global Precipitation Measurement (GPM)-based satellite precipitation estimates (SPEs) datasets in the Brazilian Central Plateau and compares it with the previous Tropical Rainfall Measurement Mission (TRMM)-era datasets. To do so, the Integrated Multi-satellitE Retrievals for GPM (IMERG)-v5 and the Global Satellite Mapping of Precipitation (GSMaP)-v7 were evaluated at their original $0.1^{\circ}$ spatial resolution and for a $0.25^{\circ}$ grid for comparison with TRMM Multi-satellite Precipitation Analysis (TMPA). The assessment was made on an annual, monthly, and daily basis for both wet and dry seasons. Overall, IMERG presents the best annual and monthly results. In both time steps, IMERG's precipitation estimations present bias with lower magnitudes and smaller root-mean-square error. However, GSMaP performs slightly better for the daily time step based on categorical and quantitative statistical analysis. Both IMERG and GSMaP estimates are seasonally influenced, with the highest difficulty in estimating precipitation occurring during the dry season. Additionally, the study indicates that GPM-based SPEs products are capable of continuing TRMM-based precipitation monitoring with similar or even better accuracy than obtained previously with the widely used TMPA product.
\end{abstract}

Keywords: IMERG; GSMaP; GPM; TMPA; TRMM; Satellite precipitation; Cerrado biome

\section{Introduction}

Precipitation is a key component of the water cycle, which is facing unprecedented changes related to both climate change and human growth population. Climate change redistributes precipitation's seasonality [1] and intensity [2], threatening the six-fold increase in water extraction observed in the 20th century in response to the increasing world population, food needs, and economics level (vision, water council, 2000). In this context, The World Meteorological Organization (WMO) defines precipitation as an Essential Climate Variable (ECV) to understand and adapt to these ongoing changes. In a general way, precipitation information obtained from point gauges measurement is spatialized to follow precipitation in time and space. However, in relation to (i) - the access difficulty (forest, desert, 
mountainous), and/or to (ii)_political, social, and economic issues, the gauges network is often too sparse and unevenly distributed to adequately follow precipitation in space and time [3,4]. It could be even more marked over tropical regions due to high spatial and temporal precipitation variability.

In this context, with an almost global coverage, remote sensing data provide relevant information to overcome these obstacles. Since the first meteorological satellite, Television and Infra-Red Observation Satellite (TIROS), launched in April 1960, a large number of sensors have been developed and used to monitor the precipitation from space [5]. They fall into two main categories: visible and infrared (VIS/IR) sensors available from geostationary (GEO) and low-earth orbiting (LEO) satellites; and passive microwave sensors (PMW) available from LEO satellites [6]. VIS/IR-based precipitation estimates use the relation between cloud-top temperature and the probability and intensity of precipitation, whereas PMW-based precipitation estimates use a more direct method related to the precipitation-sized particle. Although PMW-based precipitation estimates are a more accurate source of precipitation than VIS/IR-based estimates, the spatial and temporal coverage of LEO limits their application [7]. Indeed, a short-term precipitation event can be lost by the PMWs sensors as a result of the irregular and limited overpass of LEO [8]. VIS/IR sensors on GEO satellites can overcome this limitation since they provide high-temporal-resolution global data.

In this context, much research has been conducted seeking the development of algorithms to combine both PMW and VIS/IR observations to provide operational satellite precipitation estimates (SPEs) [5-7].

These efforts were initiated after the Tropical Rainfall Measurement Mission (TRMM) was launched, in 1997. TRMM is an international project of the National Aeronautics and Space Administration (NASA) and Japan Aerospace Exploration Agency (JAXA), from which a first generation of SPEs products was developed. TRMM-based SPEs include the TRMM Multi-Satellite Precipitation Analysis (TMPA) [9], the Climate Prediction Center Morphing technique (CMORPH) [10], the Precipitation Estimation from Remotely Sensed Information using Artificial Neural Networks (PERSIANN) [11], and the Global Satellite Mapping of Precipitation (GSMaP) [12].

To ensure continuity of the TRMM mission, the Global Precipitation Measurement (GPM) mission's Core Observatory was deployed in February 2014, with new technologies and improved global coverage as a result of opportunities from existing satellite programs and new partners obtained from bilateral agreements with either NASA or JAXA [13]. From the GPM project, a second generation of SPEs was made available to ensure continuity in precipitation monitoring started by the TRMM-based SPEs. GPM-based SPEs includes the integrated multi-satellite retrievals for GPM (IMERG) developed by NASA [14,15] and a new GSMaP version developed by JAXA [12].

If the TRMM-based SPEs have proved effective in precipitation estimation over the world, as reviewed by [16,17], GPM-based SPEs' reliability is being currently assessed and discussed by the scientific community. In the last 5 years, successive versions of the GPM-based SPEs were released. Up to date, three IMERG versions (IMERG-v3, -v4 and -v5) and two GSMaP versions (GSMaP-v6 and -v7) are available. In this context, timely studies reporting on the reliability of the successive released versions have been made available by the scientific community to contribute to the enhancement of the quality of the successively released versions.

First studies focused on the first GPM-based SPEs, IMERG version (IMERG-v3), to report on its potential improvement in precipitation estimate in comparison to its TRMM-based SPEs predecessors. A first attempt was made at the global scale by comparing IMERG-v3 with its predecessor TMPA-v7 at the monthly time step to highlight the difference in both datasets according to surfaces and precipitations rates [18]. Since then, different studies have assessed IMERG-v3's reliability at more local scales in different regions. For example, in India, IMERG-v3 shows notable improvement in comparison to TMPA-v7 to capture heavy rainfall [19] and to represent the mean monsoon rainfall and its variability [20]. In China, IMERG-v3 is more accurate than TMPA-v7 at monthly [21], sub-daily, and daily scales [22] and therefore represents a better option for hydrological applications [23]. More generally, an overall improvement from TRMM-based SPEs to IMERG-v3 were also highlighted 
in Singapore [24], Iran [25], Bolivia [26], United Arab Emirates [27], Tibet [28], East Africa [29], Continental United State (CONUS) [30], Korea, and Japan [31].

The second released IMERG version (IMERG-v4) was compared to its previous version (IMERG-v3) to highlight potential improvement on precipitation estimates accuracy. Interestingly, IMERG-v4 did not exhibit the anticipated improvement when compared to IMERG-v3 in China [32,33] and Pakistan [34] with higher bias, lower Correlation Coefficient and Root Mean Square Error. Still IMERG-v4 provides better precipitation estimates than TRMM-based SPE in Malaysia [35] and Pakistan [36].

More recently, the last released IMERG version (IMERG-v5) was compared with its former versions IMERG-v4 and -v3 in China [37] and Pakistan [34]. Both studies show a clear improvement from IMERG-v3 and -v4 to IMERG-v5. Other studies compared IMERG-v5 to TRMM-based SPEs. For example, in China, IMERG-v5 provides more reliable daily precipitation estimates than TMPA-v7 $[38,39]$ with a general superiority of IMERG-v5 for extreme rainfall event monitoring [40] and hydrological utility [41]. With an overall performance improvement, IMERG-v5 was found a suitable replacement for TMPA-v7 in Myanmar [42], Brazil [43], and CONUS [44].

It is worth mentioning that even if IMERG-v5 globally provides more accurate precipitation estimates than the TRMM-based SPEs, the opposite can be observed at the very local scale. For example, in Pakistan, at the grid-cell scale, TMPA-v7 and CMORPH-BLD provided more accurate monthly precipitation estimates than IMERG-v5 [45]. Similarly, the other GPM-based SPEs (GSMaP-v7) also provided better precipitation estimates than IMERG-v5. However, only a few studies have compared GSMaP-v7 to IMERG-v5. To our knowledge, GSMaP-v7's reliability was only assessed and compared to IMERG-v5 in Myanmar [42], Tibet [46], Pakistan [45], Brazil [43], and CONUS [44]. Therefore, there is a need to report on the latest released GPM-based SPEs versions to understand their reliability and potential complementarity.

In the described context, this study aims to evaluate the performance of the latest GPM-based IMERG-v5 and GSMaP-v7 SPEs, for the first time, over the Brazilian Central Plateau region. The assessment was made by comparing their estimates with measured data from precipitation gauges at annual, monthly, and daily scales for both wet and dry seasons, respectively. The TRMM-based TMPA-v7 dataset for a common period of data availability is also considered to assess the potential improvement of IMERG-v5 and GSMaP-v7 compared to TMPA-v7. This timely study aims to accompany the transition from TRMM to GPM-based SPE products and is expected to provide relevant information to ongoing GPM precipitation estimate algorithms and to researchers when selecting the most reliable SPEs for their studies.

\section{Data and Methodology}

\subsection{Study Area}

The study area is situated in the Brazilian Central Plateau, located between latitudes $15.5^{\circ} \mathrm{S}$ and $16.1^{\circ} \mathrm{S}$ and longitudes $47.3^{\circ} \mathrm{S}$ and $48.5^{\circ} \mathrm{S}$, where three South American river basins originate: São Francisco, Tocantins, and Paraná (Figure 1a). The region presents a mean slope value of $5.2^{\circ}(9.3 \%)$, with elevations ranging from 667 to $1356 \mathrm{~m}$ a.s.l. (Figure $1 \mathrm{~b}$ ). The study area is located in the Cerrado biome, which is exceeded in terms of area only by the Amazon and is composed of a mosaic of grass fields, savanna, and forest vegetation formations [47,48]. Recently, the Cerrado is the Brazilian region with the most important beef production, and has experienced the main expansion in total cropland area over the last two decades [49]. If the actual scenario of large-scale agriculture expansion remains, projections indicate that around $30 \%$ of the Cerrado's remaining natural vegetation is likely to be cleared in the next three decades as a consequence of limited legal protection and market pressure [50]. The climate is tropical, with a dry winter season from May to September and a rainy summer season in the remaining months, which accounts for more than $90 \%$ of average annual precipitation (Figure 1c). 


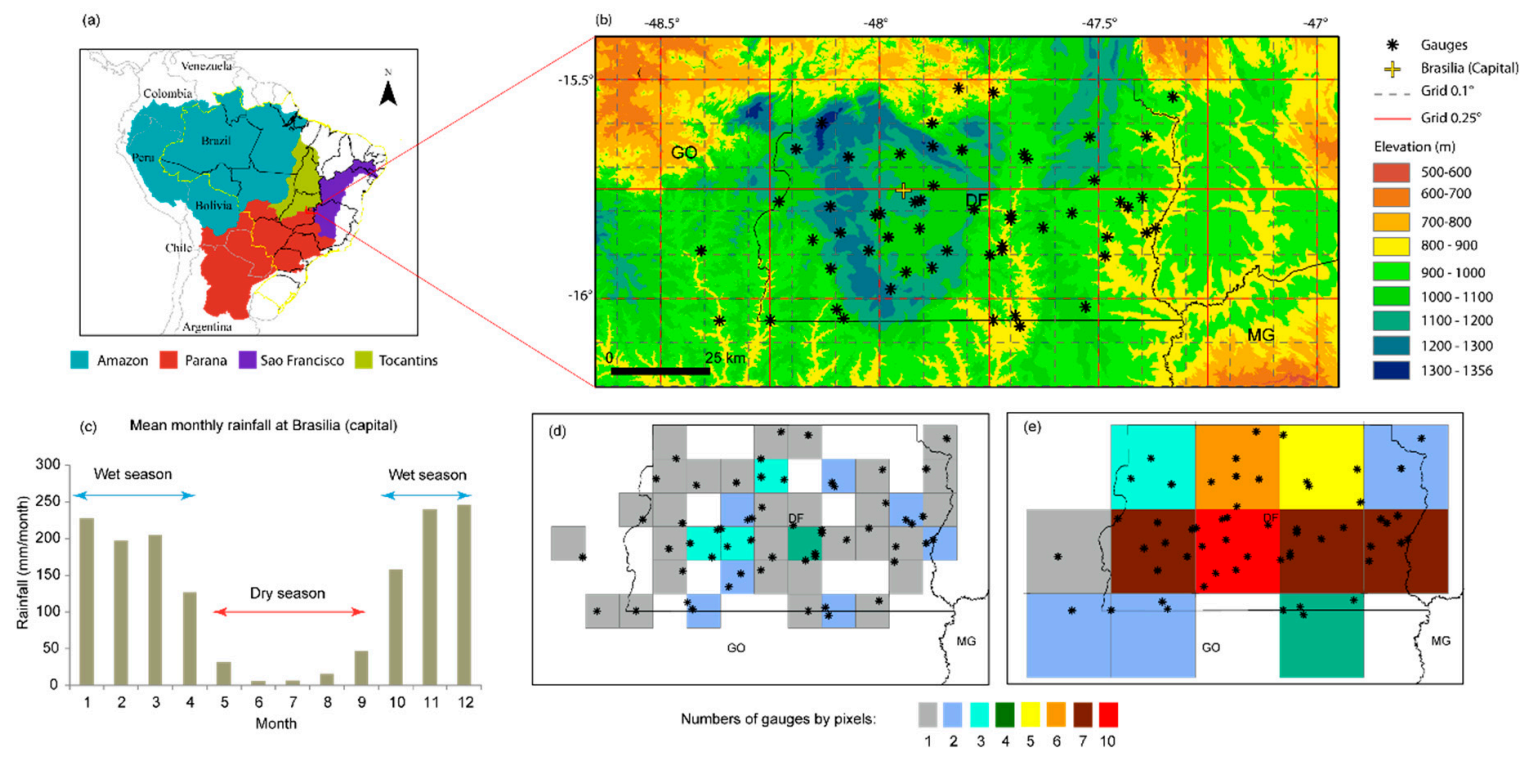

Figure 1. Study area: location within four important hydrographic regions (a); rain gauges and elevation map (b); average monthly precipitation between 1963 and 2016 for Brasilia's rain gauge (c); number of gauges by grid-cell for the $0.1^{\circ}$ grid (d); and number of gauges by grid-cell for the $0.25^{\circ}$ grid (e) .

\subsection{Precipitation Data}

\subsubsection{Integrated Multi-satellitE Retrievals for Global Precipitation Measurement (IMERG)}

IMERG is a $0.1^{\circ}$ spatial-resolution product available at $30 \mathrm{~min}$ time intervals, with spatial coverage between $60^{\circ} \mathrm{N}$ and $60^{\circ} \mathrm{S}$. IMERG is produced by NASA using concepts and components from previous algorithms: TMPA, CMORPH, and PERSIANN. Precipitation estimates from available LEO satellites' PMW sensors are assembled, gridded, and intercalibrated, then combined with data from GEO IR sensors using the Morphing-Kalman Filter, CMORPH-KF, Lagrangian time interpolation scheme, and the PERSIANN Cloud Classification System (PERSIANN-CCS) to produce half-hourly estimates [14].

There are three stage level available IMERG datasets: the early-run, providing data approximately five hours after observation time; the late-run, with approximately $16 \mathrm{~h}$ delay from observation time; and the final-run, which uses monthly precipitation data from the Global Precipitation Climatology Centre (GPCC) to perform a final adjustment [14]. The IMERG datasets are currently at version 5. In this study, only IMERG final-run version 5 (called IMERG hereafter) is considered, as it is the latest version. Early- and late-run versions were not considered, as they consist of intermediate step with an overall low efficiency due to the absence of the gauge's adjustment. Data were downloaded from the internet (ftp://arthurhou.pps.eosdis.nasa.gov/gpmdata/).

\subsubsection{Global Satellite Mapping of Precipitation (GSMaP)}

The GSMaP project was established in 2002 by the Japan Science and Technology Agency (JST) under the Core Research for Evolutional Science and Technology (CREST). Today, the activities are implemented under the Japanese Precipitation Measuring Mission (PMM) Science Team, which is a joint science team between TRMM and its successor mission, GPM [51].

The GSMaP Project has produced different SPE products from PMW, and has merged IR and PMW datasets [12,52]. This study used the $0.1^{\circ}$ spatial-resolution GSMaP product available at one-hour time interval, with coverage between $60^{\circ} \mathrm{N}$ and $60^{\circ} \mathrm{S}$, and gauge-adjusted with the Climate Prediction Center (CPC) global rain gauge daily database. This dataset uses an approach similar to CMORPH, where a moving vector derived from two successive IR images is used to propagate rainy areas from microwave radiometry. GSMaP focuses on the relationship between precipitation strength and IR 
brightness temperature, and a Kalman filter is then applied to the precipitation rate to update the rate on the IR brightness temperature [12]. Currently, the GSMaP gauge-adjusted product is in its seventh version, and will be called GSMaP hereafter. GSMaP data were downloaded from the internet (https://www.gportal.jaxa.jp/gp).

\subsubsection{Tropical Rainfall Measurement Mission Multi-Satellite Precipitation Analysis (TMPA)}

The TMPA was developed by NASA $[53,54]$ and has been widely assessed in many regions [35-38]. TMPA was developed to assemble precipitation estimates from different satellite systems with land-surface precipitation gauges in order to provide the best satellite estimate [53]. The TMPA products are produced in four stages: combination and calibration of PMW precipitation estimates using the Goddard Profiling Algorithm (GPROF); IR precipitation estimates are created using the merged PMW data; the PMW and IR are combined; and rain gauge data are re-scaled, calibrated, and used [24,53].

TMPA has a $0.25^{\circ}$ spatial resolution over $50^{\circ} \mathrm{N}$ and $50^{\circ} \mathrm{S}$, and is available at three-hour and monthly time steps, which are called 3B42 and 3B43, respectively. TMPA 3B42 has a real-time and an adjusted dataset using gauge-based data from the GPCC and the Climate Assessment and Monitoring System (CAMS) developed by the CPC. This study adopted the TMPA 3B42-v7 adjusted, available on the internet (https: / / mirador.gsfc.nasa.gov/), hereafter called TMPA.

\subsubsection{Rain Gauges}

A total of 56 rain gauges with daily records for the period from 12 March 2014 to 30 November 2016 were made available by different institutions which are responsible for quality assessment before making it available to users (Agência Reguladora de Águas, Energia e Saneamento do Distrito Federal (ADASA), Agência Nacional de Águas (ANA), Companhia de Saneamento Ambiental do Distrito Federal (CAESB), Empresa Brasileira de Pesquisa Agropecuária (EMBRAPA), and Instituto Nacional de Meteorologia (INMET)). The rain gauge network extends over approximately $6000 \mathrm{~km}^{2}$ and the stations are distributed on forty $0.1^{\circ}$ grid-cells and on twelve $0.25^{\circ}$ grid-cells (Figure 1d,e).

\subsection{Method}

\subsubsection{Pre-processing}

In order to compare IMERG and GSMaP with TMPA on a common period of data availability (12 March 2014 to 29 November 2016), it was necessary to aggregate IMERG and GSMaP values from their initial $0.1^{\circ}$ grid to TMPA's $0.25^{\circ}$ grid scale [21]. First, both IMERG and GSMaP were resampled from their $0.1^{\circ}$ grid resolution into a $0.05^{\circ}$ resolution dataset, using the nearest neighbor method. Then, from this $0.05^{\circ}$ grid, an average precipitation value was calculated for each set of $5 \times 5$ grid-cells which were within the overlapping $0.25^{\circ}$ grid [26]. Together, these two steps provided $0.25^{\circ}$ grids for IMERG and GSMaP.

This produced five different SPE datasets for the analysis: IMERG $\left(0.10^{\circ}\right), \operatorname{GSMaP}\left(0.10^{\circ}\right), \mathrm{TMPA}$ $\left(0.25^{\circ}\right)$, IMERG $\left(0.25^{\circ}\right)$, and GSMaP $\left(0.25^{\circ}\right)$. The $0.10^{\circ}$ IMERG and GSMaP grids were used to assess the impacts of the spatial resolution improvement provided by GPM datasets, while the other grids were used to compare GPM-based with TRMM-based SPE products.

In order to compare the SPEs with the in situ precipitation dataset, it was also necessary for them all to have the same temporal resolution. The precipitation values from IMERG, GSMaP, and TMPA, which were taken every $30 \mathrm{~min}$, one hour, and three hours, respectively, were converted into daily (from 12Z to 12Z), monthly, and yearly time steps.

Finally, since the number of precipitation gauges inside the same grid-cell varied from one to four on the $0.1^{\circ}$ grid (Figure $1 \mathrm{~d}$ ), and from one to ten on the $0.25^{\circ}$ grid (Figure $1 \mathrm{e}$ ), the analysis also required processing the in situ precipitation dataset before comparing it with the SPEs. An average precipitation time-series was generated from each set of gauges within each grid-cell with more than 
one precipitation gauge inside. It is worth mentioning that the number of gauges can impact the results, due to the localized nature of rainfall measurements obtained by rain gauges and to the localized precipitation events that can occur. The influence of gauge density will be addressed in the discussion section.

\subsubsection{Comparison Methodology}

According to the considered time step (annual, monthly, daily), different methods were used to compare the SPEs with the observed gauge values and to analyze the difference between them. For the monthly and daily time step assessments, two types of datasets were generated to assess the SPEs potential. The first dataset (hereafter called Mean Regional) consists of an average daily and monthly time series obtained by taking the mean of the time series records of all the grid-cells including at least one gauge. The resulting series count was 994 daily and 32 monthly values for both the $0.1^{\circ}$ and $0.25^{\circ}$ grid scale. The second dataset (hereafter called Mean Spatial) consists of records available from all the grid-cells including at least one gauge in a single series for both daily and monthly time steps. The resulting series counts were 34,799 daily and 1065 monthly values for the $0.1^{\circ}$ grid scale and 11,782 daily and 375 monthly values for the $0.25^{\circ}$ grid scale. The consideration of both Mean Spatial and Mean Regional datasets aims to assess the potential of SPEs at different spatial scales. The Mean Regional series comparisons will provide insight into the potential of SPEs at the regional scale, whereas the Mean Spatial series comparisons will provide feedback on the spatial consistency of SPEs over the considered region. Finally, both datasets (Mean Regional and Mean Spatial) were split in two according to the dry and wet season to observe the response of the SPEs to the climatic seasonality.

\subsubsection{Annual Comparison}

For the annual time step assessment, the 2015 annual precipitation maps were derived from the gauges and SPEs for the $0.1^{\circ}$ and $0.25^{\circ}$ grid to visually compare precipitation spatial distribution from all considered datasets (gauges and SPEs). Then, the 2015 annual precipitation obtained from all considered SPEs at all the grid-cells including at least one gauge were compared to the values obtained from the gauges. The comparison used the correlation coefficient (CC), the percent root-mean-square error (\%RMSE), and the percent bias (\%B) (see Equations (1)-(3)):

$$
\begin{gathered}
C C=\frac{\sum_{i=1}^{N}\left(S P E_{i}-\overline{S P E}\right)\left(P_{i}-\bar{P}\right)}{\sqrt{\sum_{i=1}^{N}\left(S P E_{i}-\overline{S P E}\right)^{2}} \sqrt{\sum_{i=1}^{N}\left(P_{i}-\bar{P}\right)^{2}}} \\
\operatorname{RMSE}(\%)=\frac{\sqrt{\frac{\sum_{i=1}^{N}\left(S P E_{i}-P_{i}\right)^{2}}{N}}}{\frac{\sum_{i=1}^{N} P_{i}}{N}} \times 100 \\
\operatorname{BIAS}(\%)=\frac{\sum_{i=1}^{N}\left(S P E_{i}-P_{i}\right)}{\sum_{i=1}^{N} P_{i}} \times 100
\end{gathered}
$$

where $\mathrm{N}$ is the number of values, $\mathrm{P}$ is the in situ observed precipitation, $\overline{\mathrm{P}}$ is the average $\mathrm{P}$ for the considered period, SPE is the precipitation estimate of the considered SPEs, and $\overline{\text { SPE}}$ is the average of the values of the SPE parameters for the considered period.

\subsubsection{Monthly Comparison}

The monthly time step analysis used the CC, \%RMSE, and \%B Equations (1)-(3) for both the Mean Regional and the Mean Spatial datasets. Previous studies assessing SPEs (e.g., [26,39-41,55]) have used the following reference values to define acceptable monthly results: CC $\geq 0.7 \%$; RMSE $\leq 50 \%$; and $\%$ B between $-10 \%$ to $10 \%$. In order to facilitate the SPEs potential inter-comparison, results are also presented in the form of a Taylor diagram [56]. The Taylor diagram shows the standard 
deviation (STD), CC, and the centered RMSE (RMSEc) values Equation (4) normalized (divided) by the reference STD.

$$
\operatorname{RMSEc}(\%)=\frac{\sqrt{\frac{\sum_{i=1}^{N}\left\{\left(\mathrm{SPE}_{\mathrm{i}}-\overline{\mathrm{SPE}}\right)-\left(\mathrm{P}_{\mathrm{i}}-\overline{\mathrm{P}}\right)\right\}^{2}}{N}}}{\frac{\sum_{i=1}^{\mathrm{N}} \mathrm{P}_{\mathrm{i}}}{\mathrm{N}}} \times 100
$$

In the Taylor diagram, the reference is presented by a black dot where the STD and the CC are equal to 1 and the RMSEc is equal to 0 . Therefore, the closer the SPEs' statistics are to the reference values, the closer their estimates are to the observed precipitation values. Additionally, for all considered SPEs, the CC, \%RMSE, and \%B are computed for all the grid-cells including at least one gauge. This aims to provide more details in the statistical score obtained from the Mean Regional datasets. The monthly analysis is performed for each dataset (Mean Regional and Mean Spatial) considering the whole period and the dry and wet season separately.

\subsubsection{Daily Comparison}

The daily time step analysis also used the CC, \%RMSE, and \%B Equations (1)-(3) for both the Mean Regional and the Mean Spatial datasets. Results are presented in the form of a Taylor diagram to facilitate the SPEs potential inter-comparison. Additionally, SPEs were also evaluated based on categorical statistics considering precipitation events as discrete values with only two possible cases (rainy day or not). Four cases are possible: (a) both SPEs and rain gauge register a precipitation event; (b) only the SPEs reports precipitation; (c) only the rain gauge registers precipitation; and (d) precipitation is not reported on either SPEs or rain gauge. After dividing data into these four classes, it was possible to calculate the probability of detection (POD), the false alarm ratio (FAR), the Critical Success Index (CSI), and the bias (B) using the following equations:

$$
\begin{gathered}
\text { POD }=\frac{a}{(a+c)} \\
\text { FAR }=\frac{b}{(a+b)} \\
C S I=\frac{a}{(a+b+c)} \\
B=\frac{(a+b)}{(a+c)}
\end{gathered}
$$

POD, FAR, and CSI vary from 0 to 1 . For POD, 1 is the perfect score and indicates the SPEs' capacity to correctly detect precipitation within the study area. CSI also has a perfect score of 1 , which represents the ratio between rain events correctly detected by the SPEs and the total rain events reported by the SPEs and the rain gauges. FAR has 0 as a perfect score, and is an indicator of how much the SPEs wrongly report precipitation when it does not occur. The success ratio (SR $=1-$ FAR) can be derived from FAR, having 1 as a perfect score. Different to POD, FAR, and CSI, $B$ does not vary from 0 to 1 . Rather, this index takes 1 as a reference value. If $B$ is higher than 1 , it indicates overestimation of the number of rain events within the SPEs product in the studied period, while values lower than 1 indicate underestimation.

A synthesis diagram was also prepared to facilitate the comparison between the categorical statistics of all considered SPEs. The performance diagram [57] builds a response surface from the geometric relationship between the POD, CSI, SR, and B, where the results of each assessed SPEs scenario are plotted. This type of analysis has been conducted in previous studies $[26,58]$, and considerably helps to interpret the global performance of the results. The daily analysis is done for each dataset (Mean Regional and Mean Spatial) considering the whole period and the dry and wet season separately. 


\section{Results}

\subsection{Annual Analysis}

Figure 2a presents the 2015 annual precipitation maps registered by the SPEs and the gauges. According to the gauge observations, the study area presents a marked west-east gradient, with the highest (lowest) precipitation occurring over the western (eastern) part (Figure 2a). Annual precipitation ranges from 800 to $1500 \mathrm{~mm}$. Despite an overall underestimation of precipitation, with $\%$ B close to $-20 \%$, GSMaP $\left(0.1^{\circ}\right.$ and $\left.0.25^{\circ}\right)$ captured the gradient (Figure $\left.2 \mathrm{a}, \mathrm{b}\right)$. On the other hand, IMERG had difficulties identifying the gradient, presenting smaller annual precipitation variability over the study area when compared to GSMaP, with annual precipitation values between 1000 and $1400 \mathrm{~mm}$. TMPA also had difficulties identifying the local gradient and registered even smaller spatial variability, with annual values ranging between 1100 and $1300 \mathrm{~mm}$, resulting in worse statistics when compared to the precipitation gauges. Moreover, the CC results presented statistical significance for all evaluated SPEs ( $p$-value $<0.01$ ), except for TMPA, in Figure 2.

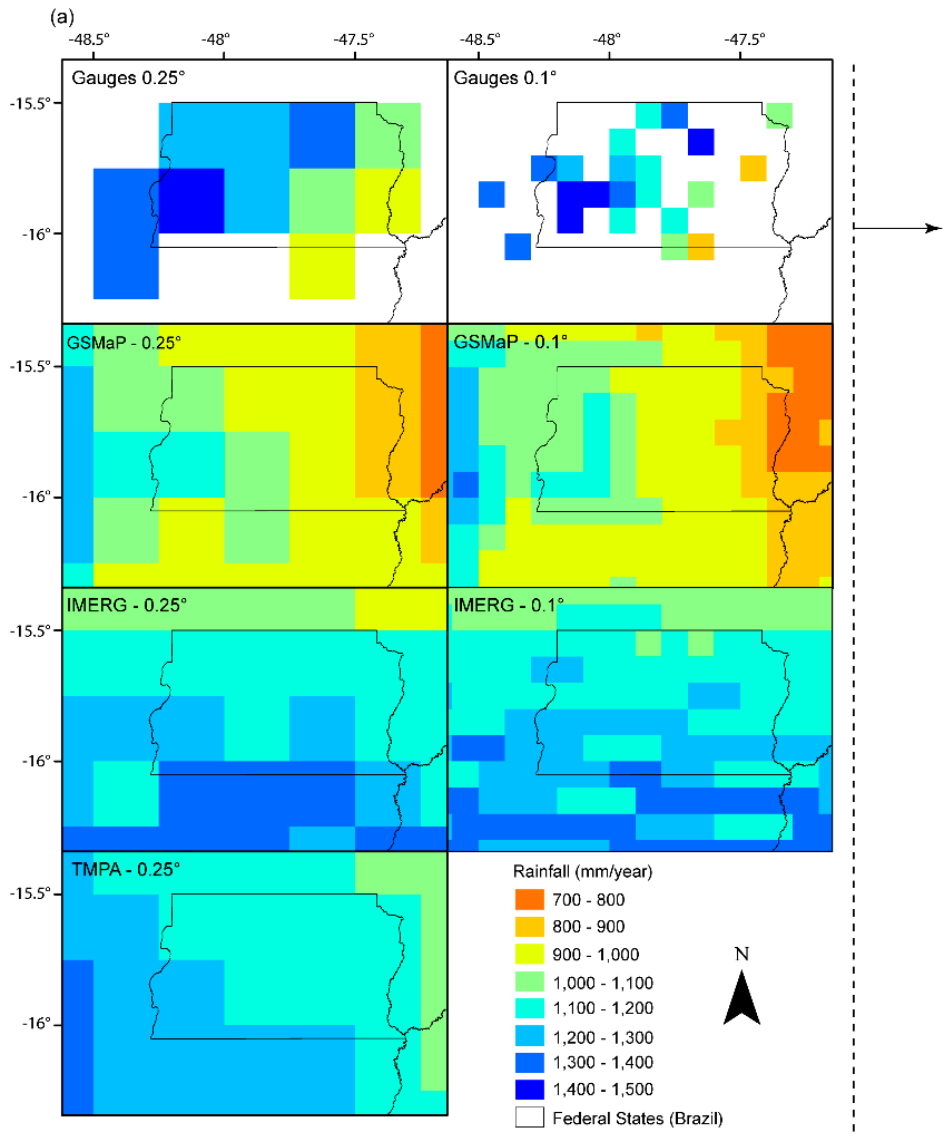

(b)

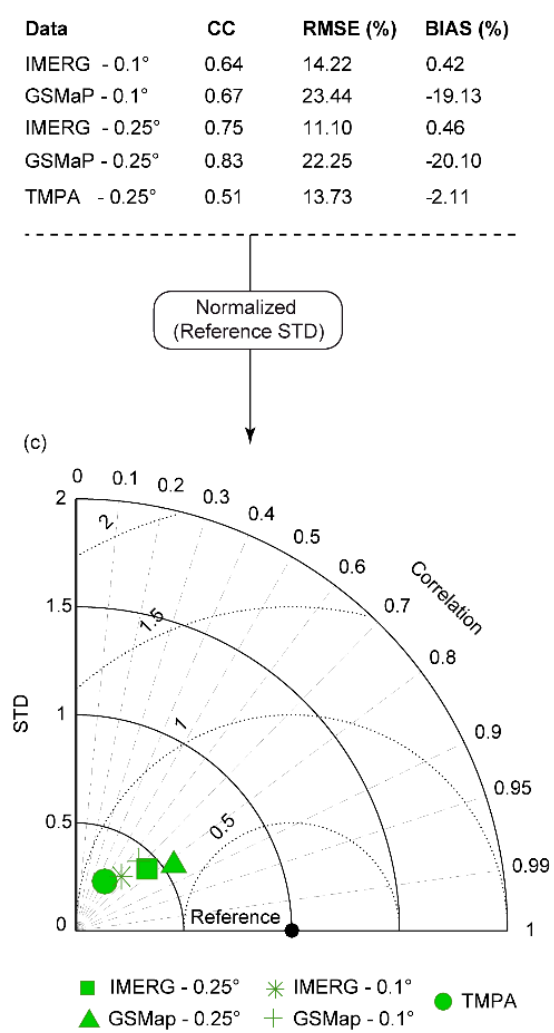

Figure 2. 2015 mean spatial annual precipitation registered by satellite precipitation estimates (SPEs) and gauges (a) and accuracy expressed in statistical metrics; (b) summarized in the form of a Taylor diagram with values normalized by the reference standard deviation (STD); (c). IMERG: Integrated Multi-satellitE Retrievals for Global Precipitation Measurement; GSMaP: Global Satellite Mapping of Precipitation; TMPA: Tropical Rainfall Measurement Mission (TRMM) Multi-satellite Precipitation Analysis; RMSE: root-mean-square error.

Despite the SPEs respective ability to represent the regional precipitation pattern, Figure 2 allows an inter-comparison of the potential of SPEs to estimate the annual precipitation amount. When comparing the GPM-based SPEs with the TRMM-based SPEs, both IMERG and GSMaP are more able to quantify the annual precipitation amount. Indeed, in the Taylor diagram (Figure 2c), 
GSMaP and IMERG for the $0.25^{\circ}$ grid are closer to the reference dot than TMPA, which locates farther from the reference dot than all the considered SPEs and resolutions. Interestingly, passing from $0.1^{\circ}$ to $0.25^{\circ}$ resolution enhances the quality of IMERG's and GSMaP's annual precipitation estimates with a slightly increase (decrease) of the CC (\%RMSE). This could be because the lower resolution tends to smooth the annual precipitation and thus to produce better results.

\subsection{Monthly Analysis}

Figure 3 shows the potential of SPEs for reproducing monthly mean regional precipitation for the inter-seasonal and for both the dry and wet seasons. The SPEs are able to capture the seasonal cycle from April 2014 to November 2016 with marked dry (from May to September) and wet (from October to April) seasons, following the reference's monthly seasonal tendency (Figure 3a,b).

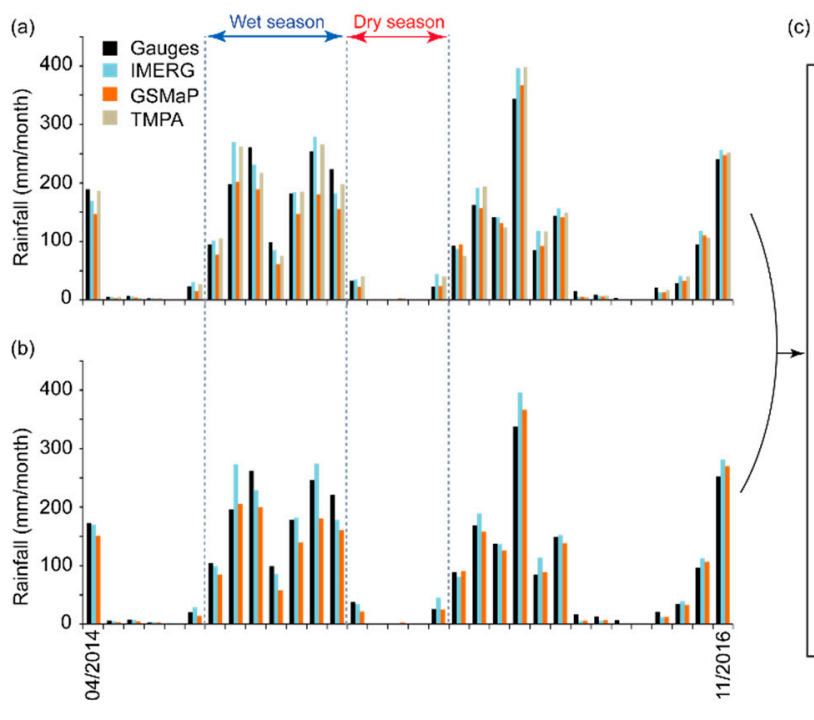

(d)

\begin{tabular}{|c|c|c|c|}
\hline \multirow[b]{2}{*}{$\begin{array}{l}\text { All period } \\
\text { IMERG }-0.25^{\circ} \\
\text { IMERG }-0.1^{\circ} \\
\text { GSMap }-0.25^{\circ} \\
\text { GSMap }-0.1^{\circ} \\
\text { TMPA }\end{array}$} & \multirow{2}{*}{$\begin{array}{l}\text { CC } \\
0.98 \\
0.98 \\
0.97 \\
0.98 \\
0.98\end{array}$} & \multicolumn{2}{|c|}{ RMSE (\%)BIAS (\%) } \\
\hline & & $\begin{array}{l}23.6 \\
24.2 \\
27.7 \\
25.5 \\
22.5\end{array}$ & $\begin{array}{l}6.2 \\
5.1 \\
-11.6 \\
-11.1 \\
4.0\end{array}$ \\
\hline \multicolumn{4}{|l|}{ Dry season } \\
\hline $\begin{array}{l}\text { IMERG }-0.25^{\circ} \\
\text { IMERG }-0.1^{\circ} \\
\text { GSMap }-0.25^{\circ} \\
\text { GSMap }-0.1^{\circ} \\
\text { TMPA }\end{array}$ & $\begin{array}{l}0.92 \\
0.91 \\
0.94 \\
0.94 \\
0.96\end{array}$ & $\begin{array}{l}68.2 \\
56.1 \\
43.7 \\
47.6 \\
55.9\end{array}$ & $\begin{array}{l}20.0 \\
3.2 \\
-21.0 \\
-29.1 \\
17.3\end{array}$ \\
\hline \multicolumn{4}{|l|}{ Wet season } \\
\hline $\begin{array}{l}\text { IMERG }-0.25^{\circ} \\
\text { IMERG }-0.1^{\circ} \\
\text { GSMap }-0.25^{\circ} \\
\text { GSMap }-0.1^{\circ} \\
\text { TMPA }\end{array}$ & $\begin{array}{l}0.95 \\
0.95 \\
0.93 \\
0.94 \\
0.95\end{array}$ & $\begin{array}{l}17.7 \\
18.4 \\
21.2 \\
19.5 \\
17.0\end{array}$ & $\begin{array}{l}5.4 \\
5.2 \\
-11.1 \\
-10.0 \\
3.3\end{array}$ \\
\hline
\end{tabular}
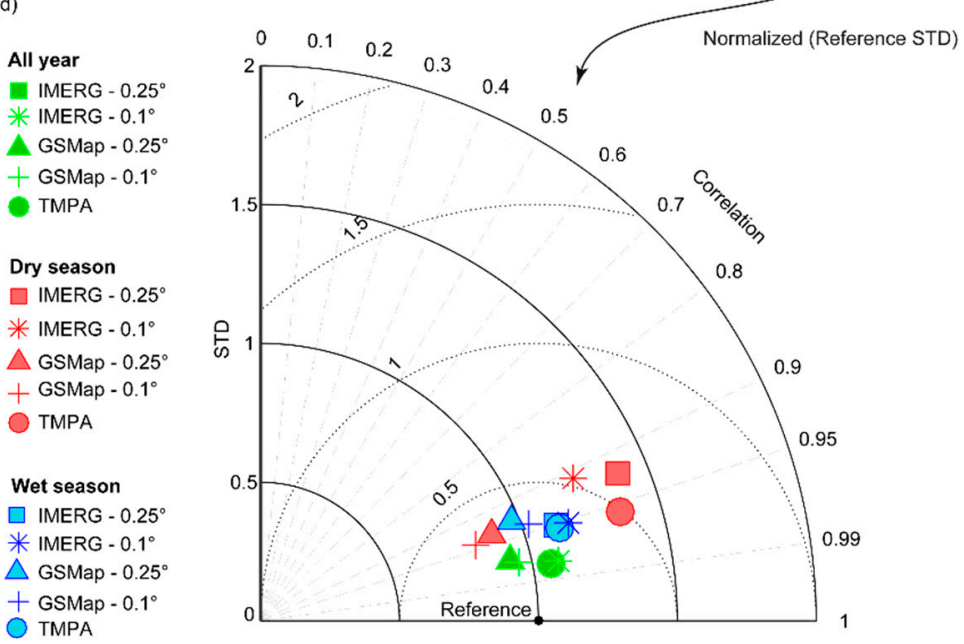

Figure 3. Mean regional monthly precipitation: values from the $0.25^{\circ}(\mathbf{a})$ and $0.1^{\circ}(\mathbf{b})$ grids; statistical results (c) and the Taylor diagram (d).

Figure $3 c$ presents the mean regional monthly CC, \%RMSE, and \%B for all considered SPEs, and Figure $3 \mathrm{~d}$ presents the Taylor diagram, which is intended to facilitate the inter-comparison of SPE potential. The CC values presented in Figure 3 were statistically significant $(p$-value $<0.01)$ for all considered SPEs and scenarios.

In the inter-seasonal analysis, all SPEs performed better than during both wet and dry seasons. Indeed, in the Taylor diagram, all SPEs' relative positions are closer to the reference dot for the 
inter-seasonal dataset. Concerning inter-seasonal evaluation, all values, except the \%B for GSMap $\left(0.1^{\circ}\right.$ and $0.25^{\circ}$ grids), are within the established quality threshold (CC $\geq 0.7 ; \%$ RMSE $<50 \%$ and $-10 \%<$ $\% \mathrm{~B}<10 \%$ ). As observed for the annual time step, GSMaP tends to underestimate the precipitation amount, with a \%B of approximately $-10 \%$ for both $0.1^{\circ}$ and $0.25^{\circ}$ spatial resolution. Overall, the new GPM-based SPEs presented similar statistics to TRMM-based SPEs in the inter-seasonal analysis, especially IMERG. This can be visually checked in the Taylor diagram, in which all SPEs present very close relative position to the reference dot (Figure 3d). Aggregating IMERG and GSMap datasets from $0.1^{\circ}$ to $0.25^{\circ}$ slightly improved their accuracy, with lower \%RMSE and \%B for both SPEs.

During the dry season, all SPEs achieved the established quality threshold for CC (CC $\geq 0.7)$, with CC systematically superior to 0.9 and the highest value obtained for TMPA $(C C=0.96)$. Regarding the \%RMSE, only GSMaP achieved the established quality threshold (\%RMSE < 50). However, the \%RMSE values of IMERG $\left(0.1^{\circ}\right)$ and TMPA $(\% R M S E=56 \%)$ are very close. With a \%B value of 3.2, only IMERG $\left(0.1^{\circ}\right)$ achieved the acceptable quality threshold $(-10<\%$ B $<10 \%)$. TMPA and IMERG $\left(0.25^{\circ}\right)$ overestimate the regional monthly precipitation amount, whereas GSMaP $\left(0.1^{\circ}\right.$ and $\left.0.25^{\circ}\right)$ underestimates the regional monthly precipitation (Figure 3). Despite a significant precipitation underestimation for GSMaP $0.1^{\circ}$ and $0.25^{\circ}$, with $\%$ B of $-29.1 \%$ and $-21 \%$, respectively, GSMaP can capture monthly regional precipitation more accurately during the dry season. Indeed, as observed in the Taylor diagram, GSMaP is closer to the reference dot than all other considered SPEs. On the contrary, IMERG is the least efficient SPE, having the farthest position from the dot reference in the Taylor diagram. It is worth mentioning that aggregating from $0.1^{\circ}$ to $0.25^{\circ}$ increased (decreased) GSMaP's (IMERG's) \%RMSE and \%B.

During the wet season, all considered SPEs present CC, \%RMSE, and \%B values that are within the established quality threshold (CC $\geq 0.7 ; \%$ RMSE $<50 \%$; and $-10 \%<\% \mathrm{~B}<10 \%$ ) with CC values systematically superior to 0.92 and \%RMSE values systematically inferior to $22 \%$. The $\% \mathrm{~B}$ of GSMaP $\left(0.25^{\circ}\right)$ was the only exception $(\% \mathrm{~B}=-11.1 \%)$, confirming the tendency of GSMaP to underestimate monthly regional precipitation amounts, as observed for the inter-seasonal and the dry season. Despite the \%B statistics, all SPEs performed similarly, as illustrated in the Taylor diagram, where their positions relative to the reference dot are very close (Figure $3 \mathrm{~d}$ ).

Finally, SPEs performed better during the wet season than during the dry season. As illustrated in Figure 3d, SPEs are closer to the reference dot for the wet season than for the dry season.

Figure 4 presents the spatial variability of monthly statistics within the study area for the inter-seasonal temporal scale in the form of \%RMSE, \%B, and CC for IMERG, GSMaP, and TMPA. It is worth mentioning that only the $0.25^{\circ}$ spatial resolution was considered, as similar results were obtained for the $0.1^{\circ}$ and $0.25^{\circ}$ resolutions for the previous annual and mean monthly regional assessments.

It is possible to notice that most of the assessed grid-cells present \%RMSE $<50 \%$, achieving the established quality threshold. TMPA and IMERG present the same \%RMSE pattern, whereas GSMaP presents two additional grid-cells with \%RMSE between 50 and $75 \%$. Regarding the $\%$ B, TMPA (GSMaP) is the SPE with the highest (lowest) proportion of grid-cell, with \%B within the established threshold $(-10 \%<\% \mathrm{~B}<10 \%)$. IMERG and TMPA present a similar spatial distribution of $\% \mathrm{~B}$, with some grid-cells overestimating the reference. On the other hand, GSMaP underestimated precipitation, with negative \%B over most of the considered grid-cells. Regarding the CC, all SPEs systematically present values within the defined quality threshold $(C C>0.7)$. All $C C$ values presented statistical significance ( $p$-value $<0.01$ ) in Figure $4 c, d)$. IMERG and TMPA presented the same CC pattern over the region, with CC superior to 0.8 over all of the considered region.

Figure $4 \mathrm{~d}$ shows the SPEs' statistics based on the Mean Spatial dataset in the form of the Taylor diagram. It aims to summarize observations from Figure $4 \mathrm{a}-\mathrm{c}$ to quantify the SPEs' potential to reproduce monthly precipitation in space for the inter-seasonal, dry, and wet seasons. With relative position closer to the reference dot, all SPEs performed better at the inter-seasonal temporal scale than on a seasonal basis. At the inter-seasonal scale, the new GPM-based SPEs present similar statistics to the TRMM-based SPEs. All three SPEs presented satisfactory statistical scores, with \%RMSE, \%B, and CC 
within the defined quality threshold except for GSMaP, which slightly underestimates the precipitation amount $(\% \mathrm{~B}=-11.5)$. Considering the seasonal scale (wet and dry seasons), all SPEs are more efficient during the wet season than during the dry season. From the wet to the dry season, \%RMSE is more than three times greater for all SPEs, \%B is twice as large for GSMaP and four times as large for both IMERG and TMPA, while a similar decrease in CC is observed for all SPEs. Consequently, none of the considered SPEs presents an \%RMSE or \%B value within the established quality threshold.

For all the considered temporal scales (inter-seasonal, wet season, dry season), the new GPM-based SPEs presented similar statistics to TRMM-based SPEs, especially IMERG. Indeed, the positions of IMERG and TMPA in the Taylor diagram are very close, and they both present similar \%B values. In the Taylor diagram, GSMaP is systematically slightly farther to the reference dot than IMERG and TMPA, highlighting an overall lower ability to represent mean monthly precipitation in space. The main difference between GSMaP and both IMERG and TMPA occurs in terms of \%B, with GSMaP underestimating precipitation amount.

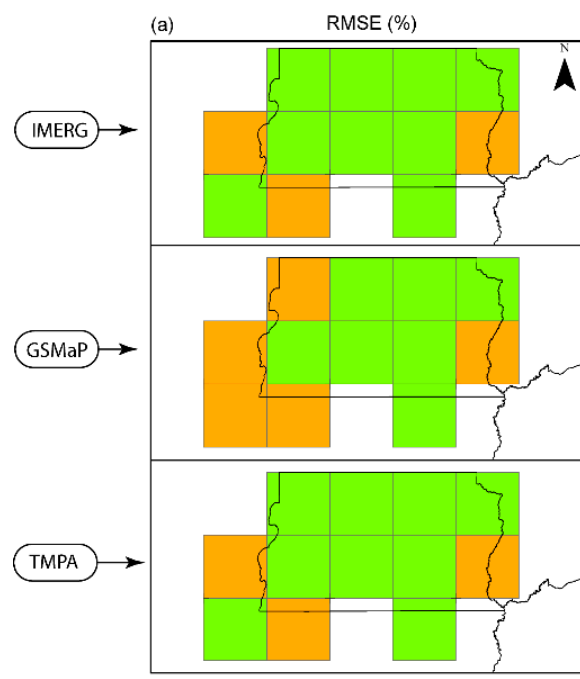

$<50 \quad 50-75$
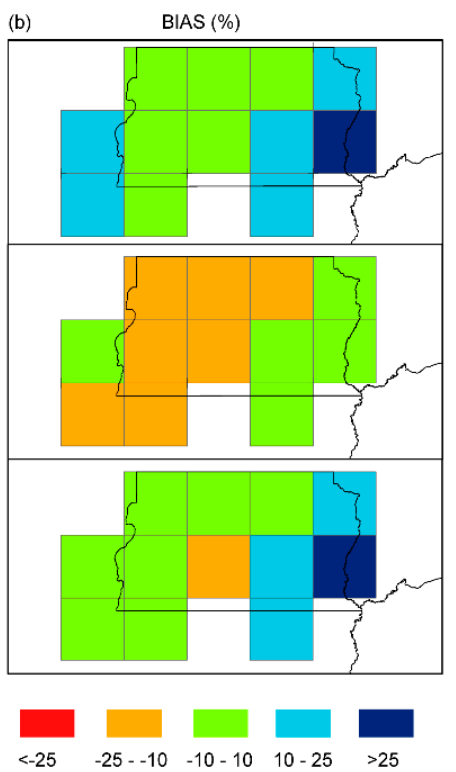
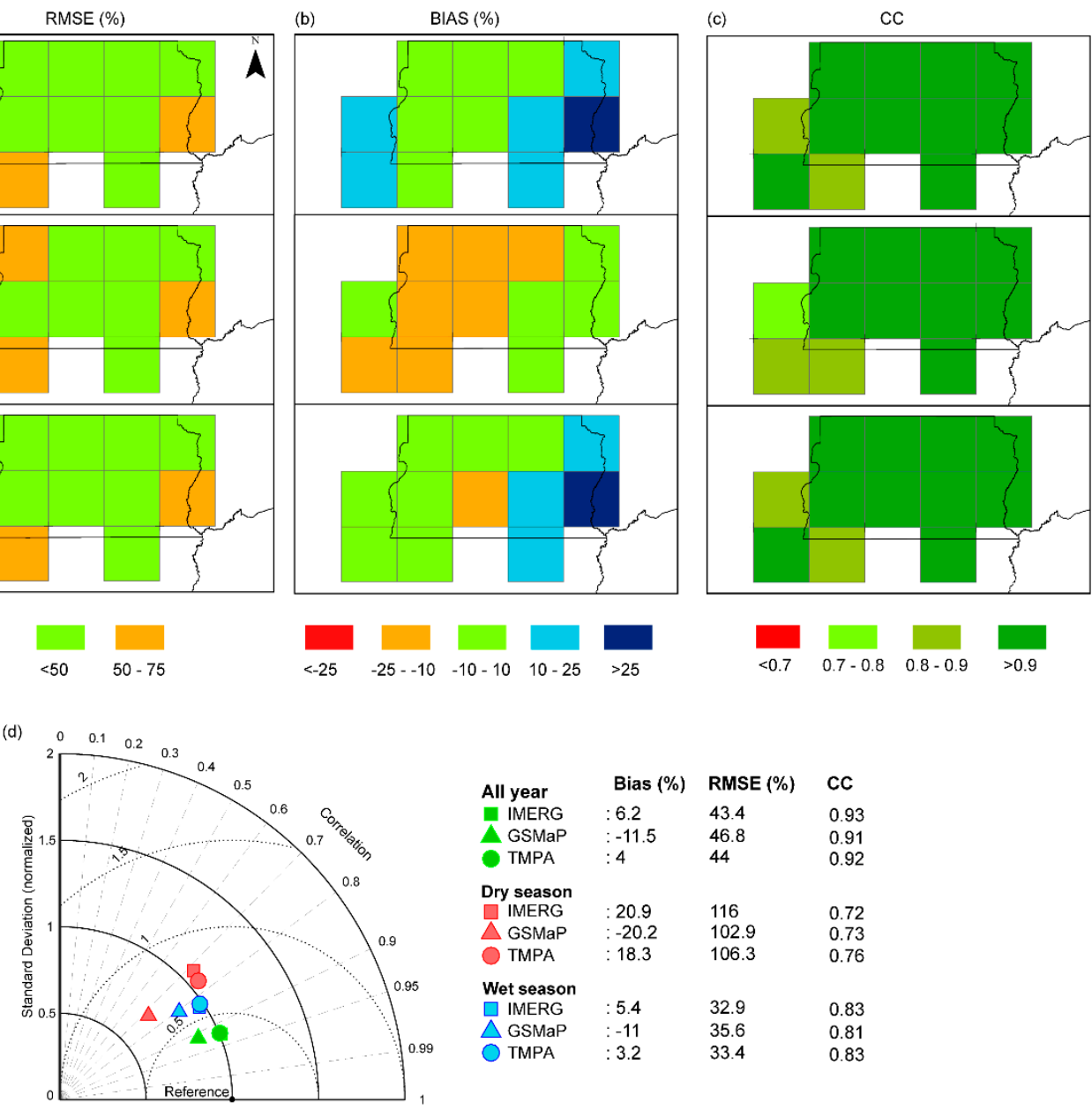

$\begin{array}{llll}\text { All year } & \text { Bias (\%) } & \text { RMSE (\%) } & \text { CC } \\ \text { IMERG } & : 6.2 & 43.4 & 0.93 \\ \text { IMSMaP } & :-11.5 & 46.8 & 0.91 \\ \text { TMPA } & : 4 & 44 & 0.92 \\ \text { Dry season } & & & \\ \text { IMERG } & : 20.9 & 116 & 0.72 \\ \triangle \text { GSMaP } & :-20.2 & 102.9 & 0.73 \\ \text { TMPA } & : 18.3 & 106.3 & 0.76 \\ \text { Wet season } & & & \\ \square \text { IMERG } & : 5.4 & 32.9 & 0.83 \\ \triangle \text { GSMaP } & :-11 & 35.6 & 0.81 \\ \text { TMPA } & : 3.2 & 33.4 & 0.83\end{array}$

Figure 4. Study area: local percent root-mean-square error (\%RMSE) (a), percent bias (\%B) (b), and correlation coefficient (CC); (c) for IMERG, GSMaP, and TMPA for the inter-seasonal scale, and Taylor diagram using the Mean Monthly datasets (d).

\subsection{Daily Analysis}

The daily analysis results are illustrated in Figure 5. The daily quantitative results are summarized in the form of a Taylor diagram for both Mean Regional (Figure 5a) and Mean Spatial (Figure 5c) precipitation datasets. The daily contingency assessment is summarized in the form of a performance diagram for both Mean Regional (Figure 5b) and Mean Spatial (Figure 5d) precipitation datasets. 


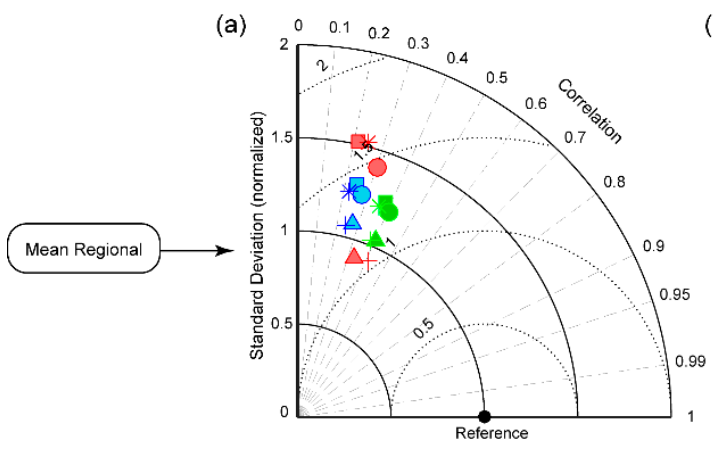

(b)

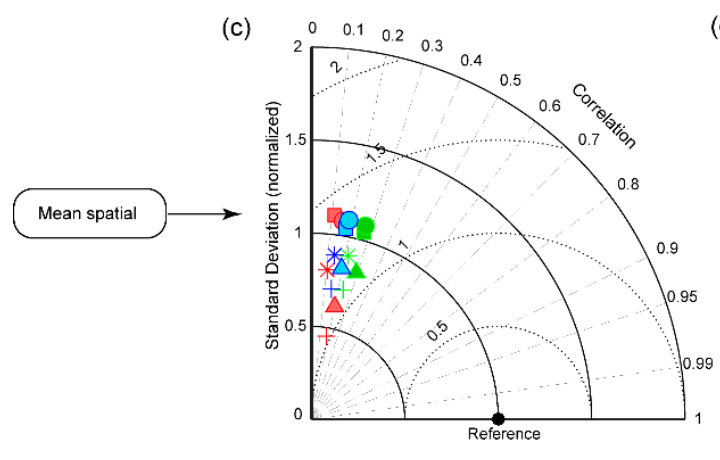

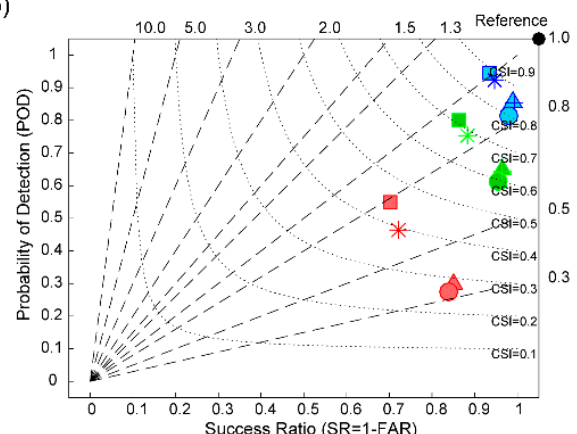

(d)

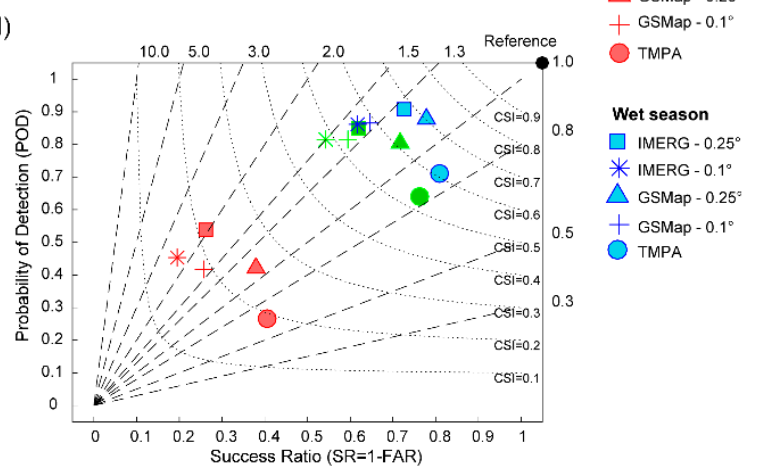

Figure 5. Mean Regional dataset daily Taylor (a) and performance; (b) diagrams, and Mean Spatial dataset Taylor; (c) and performance; (d) diagrams for: IMERG $\left(0.1^{\circ}\right)$; GSMaP $\left(0.1^{\circ}\right)$; IMERG $\left(0.25^{\circ}\right)$; $\operatorname{GSMaP}\left(0.25^{\circ}\right)$; and TMPA.

The Taylor diagram shows an overall low performance for all SPEs and both Mean Regional (Figure 5a) and Mean Spatial (Figure 5c) precipitation datasets. Indeed, all SPEs registered very low CC values, which were systematically inferior to 0.4 and 0.5 for the Mean Regional and Mean Spatial datasets, respectively. All CC values presented statistical significance $(p$-value $<0.01)$ in Figure 5a,c). Aggregation from $0.1^{\circ}$ to $0.25^{\circ}$ did not significantly improve the considered statistical metrics. Still, as observed previously in the monthly assessment, the wet season presents better statistics than the dry season and the best results are obtained for the inter-seasonal temporal scale. IMERG presents similar statistics to TMPA, with close positions on the Taylor diagram (Figure 5a,c), and GSMaP appears as the most effective SPE, with closer position to the reference dot on the Taylor diagram for all considered temporal scales (inter-seasonal, wet, and dry seasons).

Different to the daily quantitative statistical results, whose performance was unsatisfactory, as reported in the Taylor diagram (Figure 5a,c), all SPEs present a good ability to detect daily precipitation events (Figure $5 b, d$ ). The statistical scores are represented in the form of a performance diagram, in which geometric relationships between POD, SR, B, and CSI facilitate the inter-comparisons between the SPEs. The closer the SPEs are to the right-hand top corner black dot, the higher is the SPEs' potential to detect daily precipitation events. Overall, IMERG presented the best statistical scores according to the performance diagram for the Mean Regional dataset assessment (Figure 5b), while GSMaP presented the best results considering the Mean Spatial dataset (Figure 5d).

The ability of SPEs for detecting precipitation events is seasonally dependent. Indeed, for both datasets (Mean Regional and Mean Spatial), the best scores in the performance diagram are reached during the wet period, whereas the lowest scores are reached during the dry season. On the other hand, intermediate scores are reached for the inter-seasonal scale. Interestingly, aggregating IMERG and GSMaP from the $0.1^{\circ}$ grid to the $0.25^{\circ}$ grid yielded better results considering the Mean Spatial dataset, whereas no significant changes were observed considering the Mean Regional dataset. Comparing IMERG and GSMaP with TMPA for the $0.25^{\circ}$ grid shows an improvement in the ability of SPEs to detect precipitation events from the TRMM-based SPEs to the GPM-based algorithms. 
Indeed, IMERG and GSMaP are systematically located closer to the reference dot on the performance diagram than TMPA.

\section{Discussion}

In the present study, the potential of the last-released GPM-based SPEs, IMERG and GSMaP, was compared to the widely used TRMM-based TMPA SPEs. The analysis was performed considering different time steps (annual, monthly, and daily) and considering the potential seasonal effect over their precipitation estimates.

For the monthly time step, the consideration of fixed quality-threshold values highlighted the ability of SPEs to correctly capture monthly regional precipitation pattern in space and time. However, high $\mathrm{CC}$ values with unsatisfactory \%B can occur independently of the considered SPEs, which is in line with previous studies $[24,26,59]$. According to our results, a bias correction of approximately $10 \%$ is recommended before using GSMaP to follow monthly precipitation amounts. The negative bias of GSMaP supports the results of a previous study over Bolivia where GSMaP-v6 presented a \%B of approximately $-22.4 \%$ [26]. The lowest $\% \mathrm{~B}$ value in the present study $(-10 \%)$ may be the result of the improvement of the gauge calibration applied to produce the considered GSMaP-v7.

However, the inter-comparison exercise between SPEs conducted over distinct regions remains challenging and should be considered with caution. Indeed, due to the difference in spatial scale between areal (SPEs grid-cell) and point (gauges) measurement, potential conclusions using rain gauges as reference data are influenced by the gauges' locations and distribution density $[26,60]$. Precipitation events estimated by the SPEs may not be detected by the gauges, as it might rain in other location within the grid-cell area [26,55]. Therefore, part of the variability in the ability of SPEs to predict precipitation from one study to another could be attributed to the distribution density and location of the gauges used as references. In this study, data from the 56 rain gauges were aggregated into twelve $0.25^{\circ}$ grid-cells (mean of 4.7 gauges per $0.25^{\circ}$ grid-cell) with one grid-cell using up to 10 stations to calculate the reference average precipitation, whereas the 56 gauges were aggregated into forty $0.1^{\circ}$ grid-cells joining a maximum of four gauges within a grid-cell (mean of 1.4 gauges per $0.1^{\circ}$ grid-cell) (Figure $\left.1 \mathrm{~d}, \mathrm{e}\right)$. In this context, the gauges managed to better capture the precipitation variability for the coarser grid $\left(0.25^{\circ}\right)$ than for the finer grid $\left(0.1^{\circ}\right)$. Therefore, the aggregation from $0.1^{\circ}$ to $2.25^{\circ}$ slightly enhanced the quality of SPEs from IMERG and GSMaP for both monthly and daily time steps, confirming previous results [26]. To provide more insight on the conclusion reliability regarding SPEs' sensitivity to the rain gauges density, Figure 6 shows the statistical score (RMSE normalized) obtained in function of the gauge number used as reference to compare with the SPEs at the $0.25^{\circ}$ grid-cell scale. For both daily and monthly time step, the SPEs accuracy increase with the number of gauges used as reference (Figure $6 a, b)$. For example, at the daily time step, highest (1) and lowest (0) RMSE values are obtained for grid-cells counting with 1 and 10 gauges, respectively, for both IMERG and GSMaP (Figure 6a). Similarly, at the monthly time scale and for all SPEs, higher normalized RMSE is obtained when only one gauge is used as reference (Figure 6b). Therefore, different conclusion on SPEs' reliability should be drawn when using more or less dense rain gauges network as reference.

It is worth mentioning that part of the variability observed in Figure 6 could also be attributed (i) to the gauges distribution into the considered grid-cells and (ii) to the consideration of different grid-cells for the different gauge number threshold (Figure 1). Therefore, Figure 6 illustrates the potential influence of gauge density into the SPEs' reliability conclusion and more studies should be developed to clearly state on gauge density influence.

To avoid any influence of the gauge density and/or distribution on the conclusion regarding the SPEs' reliability, the SPEs could be used as forcing data in hydrological modeling. Indeed, comparing simulated streamflow using SPEs as forcing data with observed streamflow aims to enhance the quality of spatial representativeness between the assessed SPEs and the reference used [34]. 
(a)

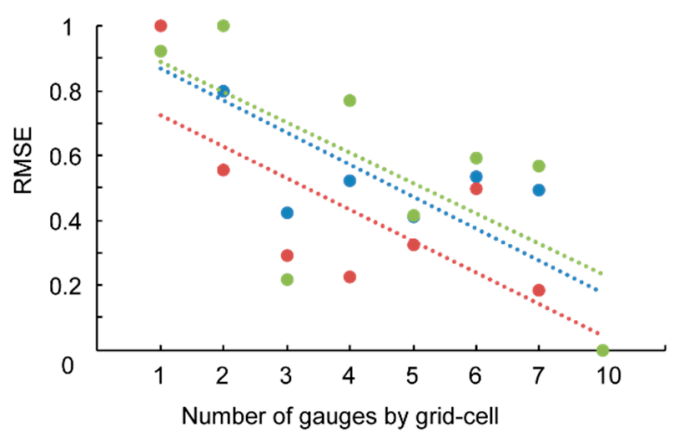

(b)

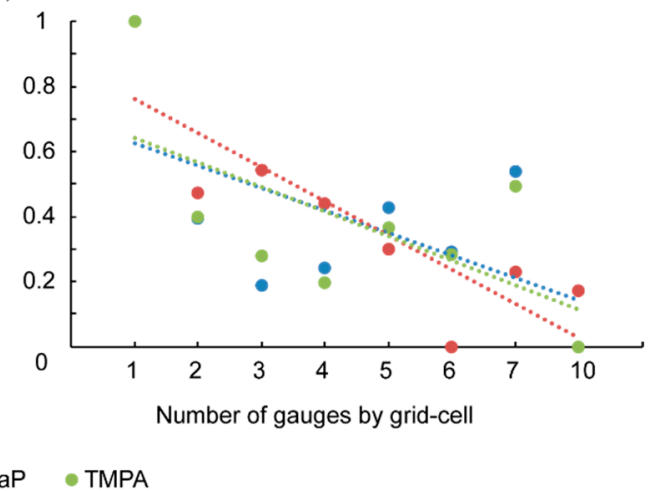

Figure 6. Gauges number influence onto the SPEs accuracy expressed in term of normalized RMSE between 0 and 1 . The analysis is applied for the $0.25^{\circ}$ grid-cells scale at both daily (a) and monthly; (b) time step. Dotted line shows the linear trends.

Additionally, the different dataset, metrics, and time scale used from one study to another complicate the inter-comparison exercise between SPEs conducted over distinct regions. Actually, as shown in the present study, the conclusions regarding the potential of SPEs differ according to the considered dataset (Mean Regional or Mean Spatial). For both the monthly and daily time steps, the SPEs appear to be globally more accurate when considering the Mean Regional dataset compared to the Mean Spatial dataset. Secondly, as observed for the daily time step, the conclusions regarding the potential of SPEs vary according to the considered metrics: quantitative (Taylor diagram) or categorical (performance diagram). SPEs were able to correctly detect daily precipitation events (categorical metrics) but failed to retrieve daily precipitation amounts (quantitative metrics). Finally, the consideration of different time scales (inter-seasonal, wet, and dry season) reveals a strong seasonal influence on the potential of SPEs, with SPEs performing better during the wet season than during the dry season for both monthly and daily time steps. This finding is in line with previous studies reporting on the influence of season on the potential of SPEs $[24,26,58,61]$. Evaluated independently, the time scale may influence the conclusion regarding the potential of the SPEs. For the above-detailed reasons, the use of variable datasets, metrics, and time scales should introduce important discrepancy on the conclusion regarding the potential of SPEs obtained from one study to another. Therefore, studies on the potential of SPEs to predict precipitation for a determined region should not be used to determine the performance of SPEs for another region, and the assessment of the potential of SPEs proves to be an essential step before their use in impact studies.

Finally, according to the presented results, the SPEs appear to be unsuitable for following the monthly precipitation dynamic during the dry season. However, this observation has to be weighted. Indeed, the mean monthly precipitation values for the dry season are very low (Figure 3). Therefore, a minimum error in precipitation estimates will automatically induce very large \%RMSE and \%B. Actually, even if large \%RMSE and \%B are observed for the dry season, these errors are insignificant regarding the total annual precipitation input over the Brazilian Central Plateau, where the dry months contribute less than $15 \%$ of the annual total precipitation. The relatively high and satisfactory CC values ( $>0.7)$ obtained by all the considered SPEs mean that the SPEs correctly capture the monthly precipitation dynamics, even during the dry season. Interestingly, during the dry season, higher distribution is observed in both the Taylor and performance diagrams, meaning that SPEs' sensitivity to low precipitation amounts or low number of precipitation events (dry season) differs more than to high precipitation amounts or large number of precipitation events (wet season). According to this study, GSMaP is the most adapted SPE to follow daily and monthly precipitation dynamics during the dry seasons over the Brazil Central Plateau region. However, as discussed before, a bias correction is strongly recommended. 


\section{Conclusions}

This study evaluated the performance of the new GPM-based SPEs in the Brazilian Central Plateau region, using data from precipitation gauges as reference. The assessment compared IMERG and GSMaP at their original $0.1^{\circ}$ spatial resolution and used an adjusted/refitted $0.25^{\circ}$ grid to compare them with TMPA on an annual, monthly, and daily basis. The major conclusions are:

- Generally, GPM-based SPEs products (IMERG, GSMaP) are able to ensure precipitation monitoring with similar or even better accuracy than that obtained previously with TRMM-based TMPA products in the Brazilian Central Plateau.

- IMERG presents the best annual and monthly results in nearly all metrics used in the analysis for all considered temporal scales (inter-seasonal, wet, and dry season).

- GSMaP precipitation estimations presented negative bias for monthly and annual precipitation amounts for all considered time scales (inter-seasonal, wet, and dry season). A bias correction of approximately $10 \%$ is recommended for monthly time step.

- $\quad$ For the daily time step, all SPEs correctly detected precipitation events but considerably failed in the quantification of daily precipitation amount. Among the considered SPEs, GSMaP presented the highest ability for detecting and quantification of daily precipitation events.

- Despite the differences between IMERG and GSMaP, their results indicate an improvement in detecting precipitation events from TRMM-based SPEs to GPM-based SPEs.

- The potential of all SPEs presented a strong seasonal variability. For both the daily and monthly time steps, all SPEs performed better during the wet season than during the dry season. The new GPM-based SPEs, IMERG and GSMaP, still have difficulty in estimating precipitation in the dry period, when precipitation events are generally less intense, of lower volume, and more sparsely distributed across the territory. Among the considered SPEs, GSMaP presents the highest ability for monthly and daily precipitation monitoring during the dry season.

More generally, this study also shows that the SPEs' reliability conclusion is sensitive to the density of the rain gauges used as reference. Indeed, more optimist/pessimist conclusions on SPEs' reliability should be drawn if considering denser/scarcer gauge network. Similarly, SPEs' reliability conclusions depend on the considered indicator. Different conclusions on SPEs' reliability can be drawn according to the considered assessment. In this line, future study should focus on the impacts of modeling sensitivity to various SPEs to assess their reliability in a more applicative context. However, for the time being, only four years of data are available for IMERG and GSMaP, which compromises robust calibration/validation steps for impact models.

Author Contributions: Conceptualization, L.S., F.S. and H.R.; Data curation, L.S., F.S., D.O. and W.F.; Formal analysis, L.S., F.S. and H.R.; Funding acquisition, T.A.; Investigation, L.S. and F.S.; Methodology, L.S., F.S. and H.R.; Project administration, L.S.; Resources, H.R., T.A., D.O. and W.F.; Software, H.R.; Supervision, H.R.; Validation, H.R. and T.A.; Visualization, L.S.; Writing-original draft, L.S. and F.S.; Writing-review and editing, L.S., F.S. and H.R.

Funding: This research received no external funding.

Acknowledgments: We thank ADASA, ANA, CAESB, and INMET for providing the rain gauge data.

Conflicts of Interest: The authors declare no conflict of interest.

\section{References}

1. Saeed, F.; Bethke, I.; Fischer, E.; Legutke, S.; Shiogama, H.; Stone, D.A.; Schleussner, C.-P. Robust changes in tropical rainy season length at $1.5^{\circ} \mathrm{C}$ and $2{ }^{\circ} \mathrm{C}$. Environ. Res. Lett. 2018, 13, 1-12. [CrossRef]

2. Fischer, E.M.; Knutti, R. Anthropogenic contribution to global occurrence of heavy-precipitation and high-temperature extremes. Nat. Clim. Chang. 2015, 5, 560. [CrossRef]

3. Li, J.D.; Heap, A. Spatial Interpolation Methods: A Review for Environmental Scientists; Geoscience Australia: Camberra, Australia, 2008; ISBN 9781921498282. 
4. Scheel, M.L.M.; Rohrer, M.; Huggel, C.; Santos Villar, D.; Silvestre, E.; Huffman, G.J. Evaluation of TRMM Multi-satellite Precipitation Analysis (TMPA) performance in the Central Andes region and its dependency on spatial and temporal resolution. Hydrol. Earth Syst. Sci. 2011, 15, 2649-2663. [CrossRef]

5. Sun, Q.; Miao, C.; Duan, Q.; Ashouri, H.; Sorroshian, S.; Hsu, K.-L. A review of global precipitation data sets: data, sources, estimation, and intercomparisons. Rev. Geophys. 2018, 56, 79-107. [CrossRef]

6. Levizzani, V.; Amorati, R.; Meneguzzo, F. A review of satellite-based rainfall estimation methods; ISAC-CNR: Bologna, Italy, 2002.

7. Kidd, C.; Levizzani, V. Status of satellite precipitation retrievals. Hydrol. Earth Syst. Sci. 2011, 15, 1109-1116. [CrossRef]

8. Tian, Y.; Peters-Lidard, C.D.; Eylander, J.B.; Joyce, R.J.; Huffman, G.J.; Adler, R.F.; Hsu, K.-L.; Turk, F.J.; Garcia, M.; Zeng, J. Component analysis of errors in satellite-based precipitation estimates. J. Geophys. Res. 2009, 114, D24101. [CrossRef]

9. Huffman, G.J.; Adler, R.F.; Bolvin, D.T.; Nelkin, E.J. The TRMM Multi-satellite Precipitation Analysis (TMPA). Satell. Rainfall Appl. Surf. Hydrol. 2010, 3-22.

10. Joyce, R.J.; Janowiak, J.E.; Arkin, P.A.; Xie, P. CMORPH: A Method that Produces Global Precipitation Estimates from Passive Microwave and Infrared Data at High Spatial and Temporal Resolution. J. Hydrometeorol. 2004, 5, 487-503. [CrossRef]

11. Sorooshian, S.; Hsu, K.-L.; Gao, X.; Gupta, H.V.; Imam, B.; Braithwaite, D. Evaluation of PERSIANN System Satellite-Based Estimates of Tropical Rainfall. Bull. Am. Meteorol. Soc. 2000, 81, 2035-2046. [CrossRef]

12. Ushio, T.; Sasashige, K.; Kubota, T.; Shige, S.; Okamoto, K.; Aonashi, K.; Inoue, T.; Takahashi, N.; Iguchi, T.; Kachi, M.; et al. A Kalman Filter Approach to the Global Satellite Mapping of Precipitation (GSMaP) from Combined Passive Microwave and Infrared Radiometric Data. J. Meteorol. Soc. Japan 2009, 87, 137-151. [CrossRef]

13. Hou, A.R.; Kakar, R.K.; Neeck, S.; Azarbarzin, A.A.; Kummerow, C.D.; Kojima, M.; Oki, R.; Nakamura, K.; Iguchi, T. The global precipitation measurement mission. Bull. Am. Meteorol. Soc. 2014, 95, 701-722. [CrossRef]

14. Huffman, G.J.; Bolvin, D.T.; Braithwaite, D.; Hsu, K.; Joyce, R.; Kidd, C.; Nelkin, E.J.; Xie, P. Algorithm Theoretical Basis Document (ATBD) Version 4.5: NASA Global Precipitation Measurement (GPM) Integrated Multi-satellitE Retrievals for GPM (IMERG); NASA: Greenbelt, MD, USA, 2015.

15. Huffman, G.; Bolvin, D.; Braithwaite, D.; Hsu, K.; Joyce, R.; Kidd, C.; Nelkin, E.J.; Sorooshian, J.T.; Xie, P. Algorithm Theoretical Basis Document (ATBD) Version 5.2: NASA Global Precipitation Measurement (GPM) Integrated Multi-satellitE Retrievals for GPM (IMERG); NASA: Greenbelt, MD, USA, 2018.

16. Maggioni, V.; Meyers, P.C.; Robinson, M.D. A Review of Merged High-Resolution Satellite Precipitation Product Accuracy during the Tropical Rainfall Measuring Mission (TRMM) Era. J. Hydrometeorol. 2016, 17, 1101-1117. [CrossRef]

17. Sun, W.; Ma, J.; Yang, G. Statistical and Hydrological Evaluations of Multi-Satellite Precipitation Products over Fujiang River Basin in Humid Southeast China. Remote Sens. 2018, 10, 1898. [CrossRef]

18. Liu, Z. Comparison of Integrated Multisatellite Retrievals for GPM (IMERG) and TRMM Multisatellite Precipitation Analysis (TMPA) Monthly Precipitation Products: Initial Results. J. Hydrometeorol. 2016, 17, 777-790. [CrossRef]

19. Prakash, S.; Mitra, A.K.; Pai, D.S.; AghaKouchak, A. From TRMM to GPM: How well can heavy rainfall be detected from space? Adv. Water Resour. 2016, 88, 1-7. [CrossRef]

20. Prakash, S.; Mitra, A.K.; AghaKouchak, A.; Liu, Z.; Norouzi, H.; Pai, D.S. A preliminary assessment of GPM-based multi-satellite precipitation estimates over a monsoon dominated region. J. Hydrol. 2018, 556, 865-876. [CrossRef]

21. Chen, F.; Li, X. Evaluation of IMERG and TRMM 3B43 monthly precipitation products over Mainland China. Remote Sens. 2016, 8, 472. [CrossRef]

22. Tang, G.; Ma, Y.; Long, D.; Zhong, L.; Hong, Y. Evaluation of GPM Day-1 IMERG and TMPA Version-7 legacy products over Mainland China at multiple spatiotemporal scales. J. Hydrol. 2016, 533, 152-167. [CrossRef]

23. Wang, Z.; Zhong, R.; Lai, C.; Chen, J. Evaluation of the GPM IMERG satellite-based precipitation products and the hydrological utility. Atmos. Res. 2017, 196, 151-163. [CrossRef]

24. Tan, M.L.; Duan, Z. Assessment of GPM and TRMM precipitation products over Singapore. Remote Sens. 2017, 9, 720. [CrossRef] 
25. Sharifi, E.; Steinacker, R.; Saghafian, B. Assessment of GPM-IMERG and Other Precipitation Products against Gauge Data under Different Topographic and Climatic Conditions in Iran: Preliminary Results. Remote Sens. 2016, 8, 135. [CrossRef]

26. Satgé, F.; Xavier, A.; Zolá, R.; Hussain, Y.; Timouk, F.; Garnier, J.; Bonnet, M.-P. Comparative Assessments of the Latest GPM Mission's Spatially Enhanced Satellite Rainfall Products over the Main Bolivian Watersheds. Remote Sens. 2017, 9, 369. [CrossRef]

27. Mahmoud, M.T.; Hamouda, M.A.; Mostafa, M. Spatiotemporal evaluation of the GPM satellite precipitation products over the United Arab Emirates. Atmos. Res. 2019, 219, 200-212. [CrossRef]

28. Xu, R.; Tian, F.; Yang, L.; Hu, H.; Lu, H.; Hou, A. Ground validation of GPM IMERG and TRMM 3B42v7 rainfall products over southern Tibetean Plateau based on high-density rain gauge network. J. Geophys. Res. Atmos. 2017, 122, 910-924. [CrossRef]

29. Sahlu, D.; Nikolopoulos, A.I.; Moges, S.A.; Anagnostou, E.N.; Hailu, D. First Evaluation of the Day-1 IMERG over the Upper Blue Nile Basin. J. Hydrometeorol. 2016, 17, 2875-2882. [CrossRef]

30. Tan, J.; Petersen, W.A.; Kirstetter, P.-E.; Tian, Y. Performance of IMERG as a Function of Spatiotemporal Scale. J. Hydrometeorol. 2017, 18, 307-319. [CrossRef] [PubMed]

31. Kim, K.; Park, J.; Baik, J.; Choi, M. Evaluation of topographical and seasonal feature using GPM IMERG and TRMM 3B42 over Far-East Asia. Atmos. Res. 2017, 187, 95-105. [CrossRef]

32. Wei, G.; Lü, H.; Crow, W.T.; Zhu, Y.; Wang, J.; Su, J. Evaluation of satellite-based precipitation products from IMERG V04A and V03D, CMORPH and TMPA with gauged rainfall in three climatologic zones in China. Remote Sens. 2018, 10, 30. [CrossRef]

33. Zhao, H.; Yang, S.; You, S.; Huang, Y.; Wang, Q.; Zhou, Q. Comprehensive evaluation of two successive V3 and V4 IMERG final run precipitation products over Mainland China. Remote Sens. 2018, 10, 34. [CrossRef]

34. Satgé, F.; Ruelland, D.; Bonnet, M.; Molina, J.; Pillco, R. Consistency of satellite-basedprecipitation products in space and over time compared with gauge observations and snow-hydrological modelling in the Lake Titicaca region. Hydrol. Earth Syst. Sci. 2019, 23, 595-619. [CrossRef]

35. Tan, M.L.; Santo, H. Comparison of GPM IMERG, TMPA 3B42 and PERSIANN-CDR satellite precipitation products over Malaysia. Atmos. Res. 2018, 202, 63-76. [CrossRef]

36. Anjum, M.N.; Ding, Y.; Shangguan, D.; Ahmad, I.; Ijaz, M.W.; Farid, H.U.; Yagoub, Y.E.; Zaman, M.; Adnan, M. Performance evaluation of latest integrated multi-satellite retrievals for Global Precipitation Measurement (IMERG) over the northern highlands of Pakistan. Atmos. Res. 2018, 205, 134-146. [CrossRef]

37. Wang, C.; Tang, G.; Han, Z.; Guo, X.; Hong, Y. Global intercomparison and regional evaluation of GPM IMERG Version-03, Version-04 and its latest Version-05 precipitation products: Similarity, difference and improvements. J. Hydrol. 2018, 564, 342-356. [CrossRef]

38. Jiang, S.; Ren, L.; Xu, C.; Yong, B.; Yuan, F.; Liu, Y.; Yang, X. Statistical and hydrological evaluation of the latest Integrated Multi-satellitE Retrievals for GPM (IMERG) over a midlatitude humid basin in South China. Atmos. Res. 2018, 214, 418-429. [CrossRef]

39. Chen, C.; Chen, Q.; Duan, Z. Multiscale Comparative Evaluation of the GPM IMERG v5 and TRMM 3B42 v7 Precipitation Products from 2015 to 2017 over a Climate Transition Area of China. Remote Sens. 2017, 944. [CrossRef]

40. Fang, J.; Yang, W.; Luan, Y.; Du, J.; Lin, A.; Zhao, L. Evaluation of the TRMM 3B42 and GPM IMERG products for extreme precipitation analysis over China. Atmos. Res. 2019, 223, 24-38. [CrossRef]

41. Yuan, F.; Wang, B.; Shi, C.; Cui, W.; Zhao, C.; Liu, Y.; Ren, L.; Zhang, L.; Zhu, Y.; Chen, T.; et al. Evaluation of hydrological utility of IMERG Final run V05 and TMPA 3B42V7 satellite precipitation products in the Yellow River source region, China. J. Hydrol. 2018, 567, 696-711. [CrossRef]

42. Yuan, F.; Zhang, L.; Min, K.; Soe, W.; Ren, L.; Zhao, C. Applications of TRMM- and GPM-Era MultipleSatellite Precipitation Products for Flood Simulations at Sub-Daily Scales in a Sparsely Gauged Watershed in Myanmar. Remote Sens. 2019, 11, 140. [CrossRef]

43. Rozante, R.; Id, D.A.V.; Chiquetto, B. Evaluation of TRMM/ PM Blended Daily Products over Brazil. Remote Sens. 2018, 10, 882. [CrossRef]

44. Beck, H.E.; Pan, M.; Roy, T.; Weedon, G.P.; Pappenberger, F.; Van Dijk, A.I.J.M.; Huffman, G.J.; Adler, R.F.; Wood, E.F. Daily evaluation of 26 precipitation datasets using Stage-IV gauge-radar data for the CONUS. Hydrol. Earth Syst. Sci. 2019, 23, 207-224. [CrossRef] 
45. Satgé, F.; Hussain, Y.; Bonnet, M.-P.; Hussain, B.; Martinez-Carvajal, H.; Akhter, G.; Uagoda, R. Benefits of the Successive GPM Based Satellite Precipitation Estimates IMERG-V03, -V04, -V05 and GSMaP-V06, -V07 Over Diverse Geomorphic and Meteorological Regions of Pakistan. Remote Sens. 2018, 10, 1373. [CrossRef]

46. Lu, D.; Yong, B. Evaluation and Hydrological Utility of the Latest GPM IMERG V5 and GSMaP V7 Precipitation Products over the Tibetan Plateau. Remote Sens. 2018, 10, 2022. [CrossRef]

47. Ratter, J.A.; Ribeiro, J.F.; Bridgewater, S. The Brazilian Cerrado Vegetation and Threats to its Biodiversity. Ann. Bot. 1997, 80, 223-230. [CrossRef]

48. Ribeiro, J.F.; Walter, B.M.T. Fitofisionomias do bioma Cerrado. In Cerrado: ambiente e flora; Sano, S.M., Almeida, S.P., Eds.; EMBRAPA-CPAC: Planaltina, Brazil, 1998; p. 556.

49. Lapola, D.M.; Martinelli, L.A.; Peres, C.A.; Ometto, J.P.H.B.; Ferreira, M.E.; Nobre, C.A.; Aguiar, A.P.D.; Bustamante, M.M.C.; Cardoso, M.F.; Costa, M.H.; et al. Pervasive transition of the Brazilian land-use system. Nat. Clim. Chang. 2014, 4, 27-35. [CrossRef]

50. Feltran-Barbieri, R.; Crouzeilles, R.; Strassburg, B.B.N.; Brooks, T.; Feltran-barbieri, R.; Iribarrem, A.; Crouzeilles, R.; Loyola, R.; Latawiec, A.E.; Filho, F.J.B.O.; et al. Moment of truth for the Cerrado hotspot. Nat. Ecol. Evol. 2017, 1, 3.

51. GsMap. Global Satellite Mapping of Precipitation (GSMaP) for GPM. Available online: https:/ / www.eorc. jaxa.jp/GPM/doc/algorithm/GSMaPforGPM_20140902_E.pdf (accessed on 10 July 2018).

52. Kubota, T.; Shige, S.; Hashizume, H.; Aonashi, K.; Takahashi, N.; Seto, S.; Hirose, M.; Takayabu, Y.N.; Ushio, T.; Nakagawa, K.; et al. Global Precipitation Map Using Satellite-Borne Microwave Radiometers by the GSMaP Project: Production and Validation. IEEE Trans. Geosci. Remote Sens. 2007, 45, 2259-2275. [CrossRef]

53. Huffman, G.J.; Bolvin, D.T.; Nelkin, E.J.; Wolff, D.B.; Adler, R.F.; Gu, G.; Hong, Y.; Bowman, K.P.; Stocker, E.F. The TRMM Multisatellite Precipitation Analysis (TMPA): Quasi-Global, Multiyear, Combined-Sensor Precipitation Estimates at Fine Scales. J. Hydrometeorol. 2007, 8, 38-55. [CrossRef]

54. Huffman, G.J.; Bolvin, D.T. TRMM and Other Data Precipitation Data Set Documentation; NASA: Greenbelt, MD, USA, 2015.

55. Hussain, Y.; Satgé, F.; Hussain, M.B. Performance of CMORPH, TMPA, and PERSIANN rainfall datasets over plain, mountainous, and glacial regions of Pakistan. Theor. Appl. Climatol. 2018, 131, 1119-1132. [CrossRef]

56. Taylor, K.E. Summarizing multiple aspects of model performance in a single diagram. J. Geophys. Res. 2001, 106, 7183-7192. [CrossRef]

57. Roebber, P.J. Visualizing Multiple Measures of Forecast Quality. Weather Forecast. 2009, 24, 601-608. [CrossRef]

58. Oliveira, R.; Maggioni, V.; Vila, D.; Morales, C. Characteristics and Diurnal Cycle of GPM Rainfall Estimates over the Central Amazon Region. Remote Sens. 2016, 8, 20. [CrossRef]

59. Yuan, F.; Zhang, L.; Win, K.; Ren, L.; Zhao, C.; Zhu, Y.; Jiang, S.; Liu, Y. Assessment of GPM and TRMM Multi-Satellite Precipitation Products in Streamflow Simulations in a Data-Sparse Mountainous Watershed in Myanmar. Remote Sens. 2017, 9, 302. [CrossRef]

60. Tang, G.; Behrangi, A.; Long, D.; Li, C.; Hong, Y. Accounting for spatiotemporal errors of gauges: A critical step to evaluate gridded precipitation products. J. Hydrol. 2018, 559, 294-306. [CrossRef]

61. Ning, S.; Wang, J.; Jin, J.; Ishidaira, H. Assessment of the Latest GPM-Era High-Resolution Satellite Precipitation Products by Comparison with Observation Gauge Data over the Chinese Mainland. Water 2016, 8, 481. [CrossRef]

(C) 2019 by the authors. Licensee MDPI, Basel, Switzerland. This article is an open access article distributed under the terms and conditions of the Creative Commons Attribution (CC BY) license (http://creativecommons.org/licenses/by/4.0/). 